\title{
Patterns of functional enzyme activity in fungus farming ambrosia beetles
}

Henrik H De Fine Licht ${ }^{1 *}$ and Peter H W Biedermann ${ }^{2}$

\begin{abstract}
Introduction: In wood-dwelling fungus-farming weevils, the so-called ambrosia beetles (Curculionidae: Scolytinae and Platypodinae), wood in the excavated tunnels is used as a medium for cultivating fungi by the combined action of digging larvae (which create more space for the fungi to grow) and of adults sowing and pruning the fungus. The beetles are obligately dependent on the fungus that provides essential vitamins, amino acids and sterols. However, to what extent microbial enzymes support fungus farming in ambrosia beetles is unknown. Here we measure (i) 13 plant cell-wall degrading enzymes in the fungus garden microbial consortium of the ambrosia beetle Xyleborinus saxesenii, including its primary fungal symbionts, in three compartments of laboratory maintained nests, at different time points after gallery foundation and (ii) four specific enzymes that may be either insect or microbially derived in X. saxesenii adult and larval individuals.

Results: We discovered that the activity of cellulases in ambrosia fungus gardens is relatively small compared to the activities of other cellulolytic enzymes. Enzyme activity in all compartments of the garden was mainly directed towards hemicellulose carbohydrates such as xylan, glucomannan and callose. Hemicellulolytic enzyme activity within the brood chamber increased with gallery age, whereas irrespective of the age of the gallery, the highest overall enzyme activity were detected in the gallery dump material expelled by the beetles. Interestingly endo- $\beta-1,3$ (4)-glucanase activity capable of callose degradation was identified in whole-body extracts of both larvae and adult

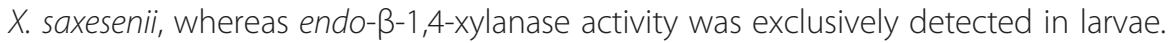

Conclusion: Similar to closely related fungi associated with bark beetles in phloem, the microbial symbionts of ambrosia beetles hardly degrade cellulose. Instead, their enzyme activity is directed mainly towards comparatively more easily accessible hemicellulose components of the ray-parenchyma cells in the wood xylem. Furthermore, the detection of xylanolytic enzymes exclusively in larvae (which feed on fungus colonized wood) and not in adults (which feed only on fungi) indicates that only larvae (pre-) digest plant cell wall structures. This implies that in $X$. saxesenii and likely also in many other ambrosia beetles, adults and larvae do not compete for the same food within their nests - in contrast, larvae increase colony fitness by facilitating enzymatic wood degradation and fungus cultivation.
\end{abstract}

Keywords: Symbiosis, Digestion, Enzyme, Insoluble chromogenic substrates, Xylomycetophagy, Xyleborinus saxesenii, Insect fungus farming, Social evolution, Division of labor

\footnotetext{
* Correspondence: Henrik.de_fine_licht@biol.lu.se

${ }^{1}$ Microbial Ecology Group, Department of Biology, Lund University, Ecology

Building, Solvegatan 37, SE-22362, Lund, Sweden

Full list of author information is available at the end of the article
} 


\section{Introduction}

Insects are the most abundant and diverse animal class on earth [1]. A key factor for their enormous success are adaptations to novel environments and food sources with the help of symbiotic microorganisms [2]. Insect hosts maintain prokaryotic, fungal, and bacterial associates in a variety of ways, which help them in nutrient acquisition and recycling, environmental detoxification, and defense against antagonists. By means of microbial symbionts insects are able (i) to detoxify toxic metabolites and (ii) to produce nutrients from plant material low in insect-accessible molecules, despite the plant material often being rich in structural polysaccharides (cross-linking glycans, cellulose and lignin) [3]. In most instances this occurs internally inside the insect host with the aid of an abundant microbial gut flora [4-6], however, there are several notable exceptions of insect lineages that cultivate microbes externally on plant material $[7,8]$. These ectosymbionts are either kept in "gardens" and consumed directly by their insect hosts (e.g. certain lineages of fungus-growing ants, termites, and ambrosia beetles; [9]), or contribute indirectly by increasing the nutrient content of the diet (e.g. bark beetles that feed on fungus infested phloem; [10]), by degradation of toxic plant compounds (e.g. terpenes by bark beetle associated fungi; $[11,12])$, or by provisioning of extracellular enzymes that facilitate wood ingestion or wood burrowing (e.g. wood wasps; $[5,13]$ ).

External symbionts of insects are typically filamentous fungi and associated yeasts and bacteria that may be transported in concert in mycetangia (also termed mycangia [14]), which are specialized organs primarily for fungal spore transmission that ensure successful reestablishment of the nutritional symbiosis after dispersal. Mycetangia have evolved independently in many different fungus associated insects such as wood and phloem feeding beetles, gall midges and wood wasps [15-17]. The active care and maintenance of the fungal crops by the insect hosts after dispersal is, however, rare. Only three insect lineages, notably the fungus-growing ants, termites and ambrosia beetles, are true fungus farmers. Within task sharing societies they not only propagate, but also actively cultivate and sustainably harvest microbial gardens without exhausting their crops across one or more offspring generations (i.e. advanced fungiculture; [9]).

Ambrosia beetle is an ecological term used for all weevils that farm fungi within tunnel systems (galleries) in the xylem (= wood) of trees. Ambrosia farming is only found in Scolytinae and Platypodinae and evolved repeatedly at least nine times from the phloem feeding habit without any known reversal to non-farming $[18,19]$. Female ambrosia beetles seek out recently dead trees where they bore into the xylem and initiate nest building by laying eggs and inoculating tunnel walls with mutualistic fungi. When larvae emerge they feed on the fungus and in some species further expand the gallery [20]. Depending on the species and environmental conditions adults repeat this cycle by either dispersing immediately following pupation or remain in their natal gallery and engage in cooperative breeding for more generations before dispersing [9,21].

The relationship between ambrosia beetles and their fungi is often species (or genus) specific, with highly selective transmission of the primary symbionts in mycetangia by dispersing beetles $[20,22]$. These so-called ambrosia fungi (usually species of the ascomycete genera Ambrosiella and Raffaelea) form layers of conidiophores on the tunnel walls that produce nutrient rich conidiospores for larval and adult beetle nutrition. Secondary symbionts, such as other filamentous fungi (e.g. Fusarium, Graphium, Ophiostoma, Paecilomyces, Penicillium [23,24]), yeasts (e.g. Candida [25]) and bacteria [26,27], are also present within galleries and often passively vectored in small amounts attached to the integuments of dispersing females $[15,20]$. However, the primary mutualistic ambrosia fungus is known for only a minority of the 3000 species worldwide [28-30], and there has only been a single attempt to characterize the entire microbiome of an ambrosia gallery [31].

Studies on the dynamics of filamentous fungi in xyleborine ambrosia beetle galleries [23,24], suggest that propagates of mutualistic ambrosia fungi (Ambrosiella and Raffaelea) are passively spread on tunnel walls from the mycetangia or via beetle feces during the excavation by the gallery founding female. This ensures that the mutualistic fungi dominate the gallery microbial flora initially while eggs are laid and larvae develop. Later, when the first offspring mature, other saprobic fungi (secondary symbionts like Penicillium and Paecilomyces) start to appear and increase in frequency over time. These opportunistic fungi dominate the microbial gallery flora at the time when the gallery is abandoned and all individuals disperse to found new galleries [23]. The secondary symbionts also dominate in the gallery dumps of our study species, the ambrosia beetle Xyleborinus saxesenii (Fruit-tree pinhole borer); they are relatively rare in freshly excavated parts of the brood chamber and their presence negatively affects larval numbers [24].

Larvae of $X$. saxesenii do not only feed on ambrosia fungi, like the adults and larvae of many other ambrosia beetles, but feed xylomycetophagously (i.e. feeding on fungus infested wood) [32]. In this way they (a) create more space for the developing fungus to form conidiophores on the gallery walls, (b) lower competition between group members by enlargement of the nest space, (c), likely reduce the growth of unidentified molds, possibly by gregariously feeding on them [21], and (d) 
fertilize the growing ambrosia fungus with the finely fragmented woody sawdust in their feces [21,33]. This apparently allows $X$. saxesenii, and probably other xylomycetophagous ambrosia beetle species, to establish galleries for several consecutive offspring generations. However, nothing is known about the mechanism or the enzymatic machinery whereby these beetles together with the consortium of symbiotic fungi utilize the surrounding wood.

In contrast to xylem dwelling ambrosia beetles, weevils dwelling in the inner bark phloem and feeding phloeophagously (phloem feeding) or phloeomycetophagously (feeding on fungus infested phloem) are termed bark beetles [20]. Their primary associates, the ophiostomatoid fungi, are close relatives of ambrosia fungi and are known to produce a variety of hemicellulolytic enzymes [34-38], although Ophiostoma fungi in general leave the cellulose and cross-linking glycans mostly intact and instead utilize storage products in the living ray parenchyma [29]. The beetles and internal gut microbes may also contribute enzymes as larvae of a bark beetle (Phloeosinus bicolor) showed $\alpha$-amylase-, invertase-, maltase-, lactase-, and protease-activities together with some hydrolytic activity on a substrate of hemicellulose but not on cellulose [39]. Similarly, in adults of the phloem feeding Ips cembrae consistent activity against hemicellulose together with pectinase-, $\alpha$-glucosidase-, $\beta$-glucosidase-, $\alpha$-galactosidase-, $\beta$-galactosidase-, trehalase-, serine protease-, peptidase-, and lipase-activities were detected in the intestinal lumen [40]. In general, the bark beetle associated fungi (e.g. the genera Ceratosytiopsis, Entomocorticium, Grosmannia and Ophiostoma $[41,42])$, in addition to associated yeasts $[12,41,43]$, and bacteria $[44,45]$ are capable of producing a variety of enzymes catalyzing (a) protein/peptide degradation (endo-, exoproteases and peptidases), (b) polysaccharide/ starch/sugar degradation (glycoside-hydrolytic enzymes) and (c) fat/fatty acid degradation (lipases) [34-36,41, 42,46-49].

Here the activity of the major groups of plant cell-wall degrading enzymes: cellulases, hemicellulases, pectinases, in addition to proteases and $\alpha$-amylases in the ambrosia beetle system are investigated for the first time. We take advantage of a recently developed method to maintain ambrosia beetle galleries of $X$. saxesenii for consecutive generations in-vitro in the laboratory [50]. We show that ambrosia beetles and their associated microbiome mainly degrade the hemicellulose component of xylem wood in addition to more readily degradable simple sugars. Furthermore, we document that larvae and adults possess different enzyme profiles, which adds an additional layer of complexity to the division of behavioral tasks between life-stages already reported within the highly social societies of $X$. saxesenii [21].

\section{Results}

\section{Gallery enzyme activity}

We measured enzyme activity of samples taken at three time points after gallery foundation in all three gallery compartments (Figure 1A): (1) gallery dump samples, containing all the waste-material (sawdust, feces, fungus) that is shuffled out of the entrance tunnel by the adult females, (2) samples of the fungus infested substrate from the walls of the entrance tunnel, which is the oldest part of the nest and vertically penetrates the substrate, and (3) samples of the fungus infested substrate of the brood chamber, where the major part of the mutualistic fungus is growing and the brood is developing. Six specific enzyme activities (endo- $\beta-1,4-$ glucanase, endo- $\beta-1,3(4)$-glucanase, endo- $\beta-1,4$-xylanase (xylan and arabinoxylan), endo- $\beta-1,4-$ mannanase, and endo-protease (casein)) were consistently detected in all gallery samples when using 13 different enzymatic substrates (Figure 1B, [Additional file 1: Figure S1]). Enzyme activities varied significantly between the three gallery compartments (log-likelihood ANOVA comparison of final mixed models with reduced null models: likelihood-ratio $\left.{ }_{3,5}=14.1-50.4, p=<0.0001-0.0009\right)$, but were not significantly influenced by the number of larvae and adults present in the gallery at the time of wall-material sampling (log-likelihood ANOVA comparison of final mixed models with reduced null models: likelihood-ratio ${ }_{5,11}=2.0-8.7, p=0.1884-0.9169$ ). The plant cell-wall degrading cellulases, endo-xylanases and pectinases had a consistently higher activity in the gallery dump material compared to the entrance tunnel and the brood chamber (Figure 1B, [Additional file 1: Figure S1]), whereas endo-protease activity against casein showed the opposite trend with the highest enzyme activity in the entrance tunnel (Figure 1B, [Additional file 1: S1]). The increased enzyme activity of plant cell-wall degrading enzymes in the gallery dump was also evident from the partial least square regression analysis because these specific enzymes correlated (i.e. clustered) more closely to the gallery dump than both the entrance tunnel and the brood chamber [see Additional file 1].

Cellulolytic activity was similar between the entrance tunnel and brood chamber across gallery ages, whereas endo- $\beta-1,4$-xylanase (xylan and arabinoxylan) and endo$\beta-1,4$-mannanase activity changed across age cohorts most notably with an increase in enzyme activity in the gallery dump over time (log-likelihood ANOVA comparison of final mixed models with reduced null models: likelihood-ratio ${ }_{5,11}=12.7-16.9, p=0.0095-0.0472$, Figure 1B). For these three enzymes we also noted a consistent but non-significant trend of higher activity in the entrance tunnel compared to the brood chamber at age 45 (i.e., 45 days after gallery foundation), similar 


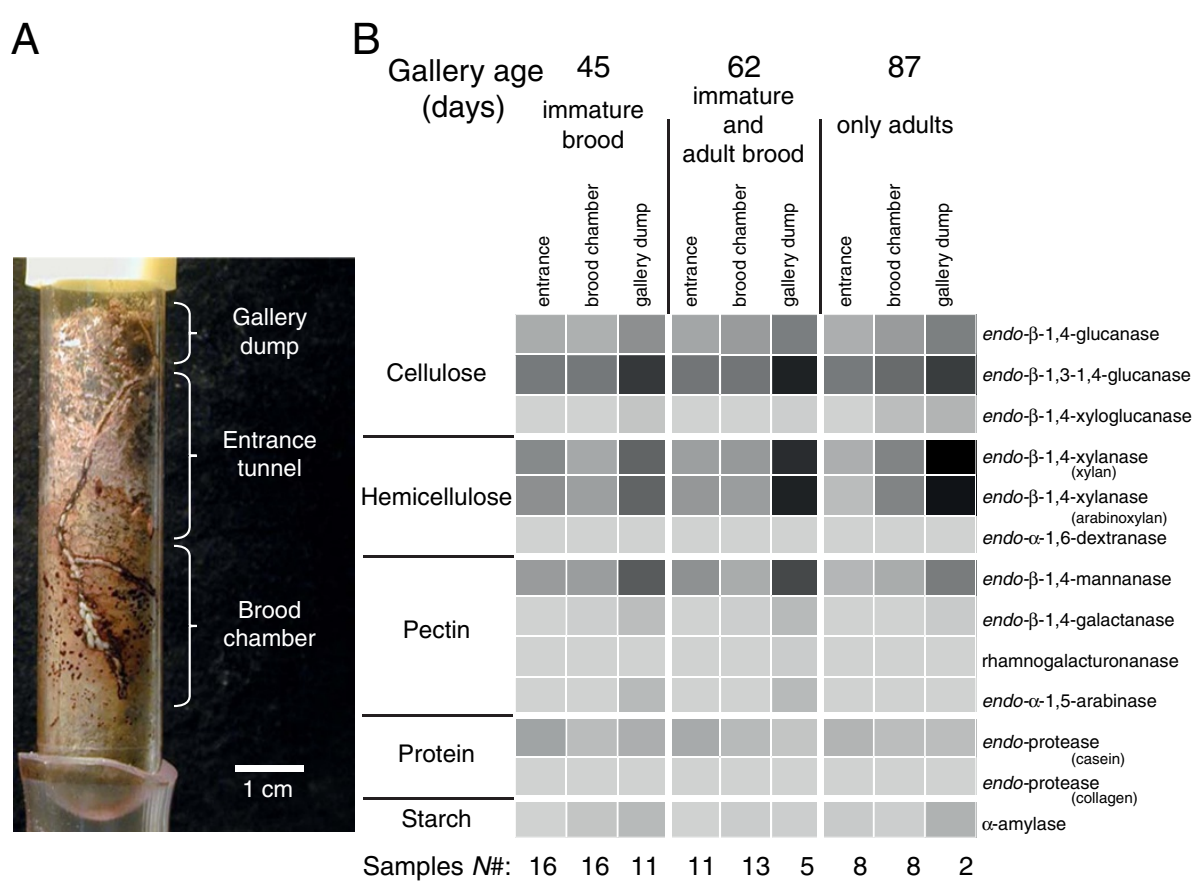

Figure 1 Glycoside hydrolytic enzyme activity of $X$. saxesenii ambrosia beetle galleries. A. Picture of a X. saxesenii gallery in artificial media around day 45 after gallery foundation. Note the three distinct compartments, where samples for enzyme activity measurements were collected: entrance tunnel, brood chamber, and gallery dump. Many white larvae and a few light brown teneral females are visible in the brood chamber and the lower part of the entrance tunnel. B. Enzyme activity of 13 specific carbohydrate active enzymes presented as a heatmap with darker coloration showing higher enzyme activity. Enzyme activity was measured when only immature brood was present, when both immature and adult brood were present, and finally when only adult brood were present 45,62 and 87 days respectively, after gallery foundation by a single mated female). Enzymes are divided into functional groups according to the plant cell structure functioning as substrate for enzymatic hydrolysis.

activity at age62 and the opposite pattern at age87 [see Additional file 1].

Enzyme activity against the substrates xyloglucan, galactan, rhamnogalacturonan, debranched arabinan and amylose tended to be highest in the gallery dump [see Additional file 1]. Because these enzyme activities were only sporadically detected, we analyzed each age cohort separately using a non-parametric Kruskal-Wallis test [see Additional file 1]. Enzyme activities against the substrates dextran and collagen were not detected in any sample (Figure 1B).

\section{Adult and larvae enzyme activity}

Endo- $\beta$-1,3(4)-glucanase (beta-glucan) activity was detected in $1^{\text {st }}, 2^{\text {nd }} / 3^{\text {rd }}$ instar larvae and adults (Figure 2 ), whereas endo- $\beta$-1,4-xylanase activity was detected in $1^{\text {st }}$ to $3^{\text {rd }}$ instar larvae with highest activity during $2^{\text {nd }}$ and $3^{\text {rd }}$ instars, but not in adult beetles (Figure 2). No statistical analysis was performed on enzyme activities extracted from larvae or beetles because although samples were approximately standardized to the same total biomass the inherent physiological difference between larvae and adult would render the result ambiguous. No endo- $\beta$-1,4-glucanase or endo-protease (casein) activity were detected in adults or larvae (Figure 2).

\section{Discussion}

\section{Gallery enzyme activity}

Plant cell-wall degrading cellulases, endo-xylanases and the pectinolytic endo- $\beta-1,4$-mannanase dominate the enzymatic profile but also consistent endo-protease activity against casein were detected at all measured time-points in all three gallery compartments (Figure 1B). Taken together the enzymatic profile of the microbial consortium of $X$. saxesenii ambrosia galleries resembles that of common saprotrophic ascomycete and basidiomycete fungi [51-53], highlighting the universal similarity of enzymes required in the initial degradation of recently dead wood material. The production of extracellular enzymes by filamentous fungi is highly dependent on the growth medium and external conditions such as temperature and moisture etc. [51]. Hence it is extremely difficult if not impossible to obtain natural enzyme activity profiles under in-vitro laboratory conditions, as the actual micro-habitat experienced by microbes in nature cannot be fully replicated. The relatively high endo-protease and possibly also $\alpha$-amylase activity detected in our samples (Figure 1B), for example, is most likely because of casein and starch used in the artificial breeding medium and does not reflect the natural situation. Despite this caveat, the detailed enzymatic measurements of laboratory 


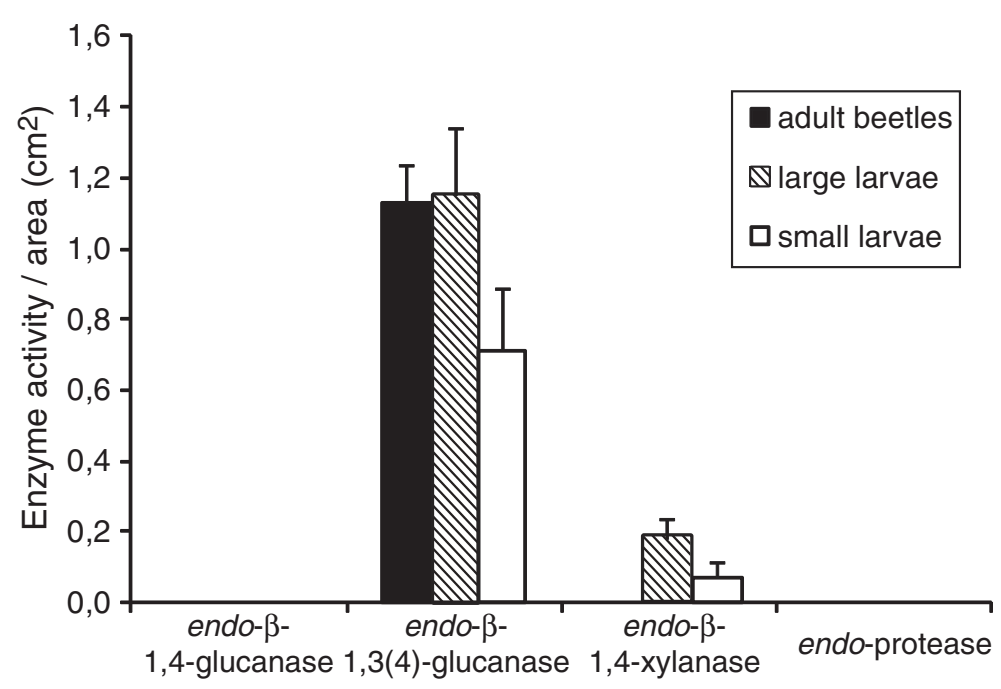

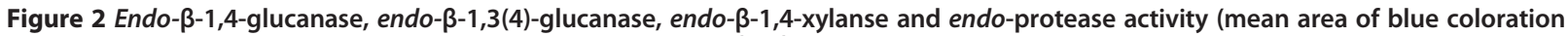
in AZCL-plate assays + SE) of adult ( $n=14 \times 3$ adults), large $\left(2^{\text {nd }} / 3^{\text {rd }}\right.$ instar, $n=14 \times 4$ larvae) and small $\left(1^{\text {st }}\right.$ instar, $n=8 \times 12$ larvae) $X$.

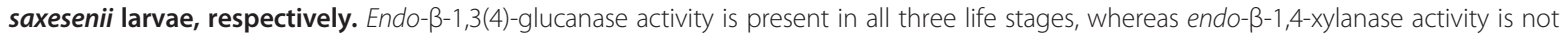
present in adult beetles but only detected in large and small larvae.

maintained and age-controlled beetle galleries containing all the naturally vectored symbiotic microbes provide an informative substitute for natural measurements of the highly inaccessible ambrosia beetle galleries deep inside wood.

Endo-xylanase activity increased in the brood chamber, but decreased in the entrance tunnel with gallery age ([Additional file 1: Figure S1]). In addition, when comparing the endo- $\beta-1,4$-glucanase and endo- $\beta-1,4-$ mannanase activity between compartments within galleries, samples from the entrance tunnel and brood chamber showed remarkably similar enzymatic profiles, whereas gallery dump samples had much higher activities (Figure 1B). These changes in enzymatic activity most likely reflected progression in the degradation of the wood substrate surrounding the galleries. Only cellulase activity was remarkably similar and low in all gallery compartments at all age stages (Figure 1B). Unfortunately, we are unable to distinguish whether these shifts in enzyme activity are due to changes (i) in beetle activities, (ii) in endo-xylanase production by the resident microbes, or (iii) in the succession of microbes in the galleries. Ambrosia beetle galleries are not static environments and conditions (e.g. humidity, degradation) and the composition of the associated microbial consortium changes both between gallery compartments and as tunnel parts age. Ambrosia fungi, as the primary food source for the beetles, only dominate the microbiome in freshly excavated gallery parts where the brood develop and are later replaced by secondary saprobic symbionts that continue degradation [23,24]. Therefore, the observed enzyme activity in the expelled sawdust material in the gallery dump is likely produced by opportunistic bacteria and fungi not necessarily involved in the nutrition of the insects, as found in certain fungusgrowing ant dumps [54]. The expelled saw-dust is probably of little nutritional value and instead represents a source of potential contamination that needs removal [9]. However, this begs the question how the relatively lower enzyme activity of the microbial consortium in the freshly excavated gallery parts is able to sustain ambrosia beetle nutrition? The high hemicellulolytic activity against xylan, glucomannan and callose, but only little activity against cellulose (Figure 1B), show that the gallery microbiome preferentially degrades hemicellulose components of the ray-parenchyma cells in the xylem. This is in contrast to bark beetle microbiomes in the phloem, which apparently leaves almost all of the structural plant cell wall components (cellulose, hemicellulose and pectin) intact [29]. Degradation of hemicellulose components is energetically less costly than complete cellulose degradation [51], however, the reliance on hemicellulases emphasizes that the xylem niche within recently dead wood is transient before the microbiome has to be provisioned with new material either by excavation of tunnel systems or dispersal to new hosts. Indeed, ambrosia beetles leave their galleries with their mutualists stored in mycetangia when opportunistic saprobes invade [23], which may coincide with depletion of the more easily accessible plant cell wall components.

\section{Adult and larvae enzyme activity}

Endosymbionts play a crucial role in nutrient acquisition in many wood-feeding arthropods, like termites or wood-boring beetles $[2,4,49]$. In bark and ambrosia beetles they seem of minor importance because these 
beetles feed either on (fungus infested) phloem (i.e. bark beetles) or fungi/fungus infested xylem (i.e. ambrosia beetles). The gut flora of ambrosia beetles has not been studied, but for bark beetles the species richness in larval and adult guts is relatively low $[45,55]$. The endosymbiotic yeasts and bacteria in bark beetles have been shown to detoxify poisonous wood compounds (e.g. tannins [11]) and fix nitrogen [56]. However, their role for degradation appears rather small compared to the primary fungal ectosymbionts that are growing within the galleries of Ips and Dendroctonus beetles [45,55]. As most ambrosia beetle species feed solely on fungus tissue, an endogenous production of plant cell wall degrading enzymes either by the beetles or associated endosymbionts in these species is not expected, but this may be different in larvae of $X$. saxesenii and other ambrosia beetles in the genus Xyleborinus that ingest both fungal tissue and particles of wood while feeding [21,32]. Indeed, the different nutrition of larvae and adults in $X$. saxesenii was also reflected by endo- $\beta-1,4$-xylanase activity observed in whole-body extracts of larvae, but not of adults (Figure 2). Endo- $\beta$-1,4-xylanase enzymes might be produced by gut endosymbionts that are either specific to the larvae (larval specific bacteria are known from Ips and Dendroctonus bark beetles [55,57]), or endosymbionts are present in both larvae and adults but facultatively produce and secrete endo- $\beta-1,4$-xylanases depending on context. A microbial origin of these enzymes is possible because insects are rarely capable of producing plant cell-wall degrading enzymes themselves, although an increasing number of putative genes coding for cellulases, hemicellulases and pectinases are being discovered in the genomes of wood dwelling beetles [58], which in certain cases appear to be horizontally acquired from bacteria $[59,60]$. A few beetle species have been shown to synthesize xylanase endogenously, for example larvae and adults of the wood-boring beetle Phaedon cochleariae [61] and the coffee-berry borer Hypothenemus hampei [UniProt:E2J6M9]. The latter is a scolytine beetle, and it therefore is possible that the endo- $\beta-1,3(4)$-glucanases and endo- $\beta-1,4-x y l a n a s e s$ found in our study may be endogenously produced by $X$. saxesenii.

A third possibility is that larval and adult plant cellwall degrading enzymes are of ectosymbiotic origin, i.e., they are fungus derived. Enzyme acquisition by feeding on fungi is well known from several fungal-insect mutualisms (c.f. the acquired enzyme hypothesis [13,62], Table 1). Related bark beetles carry yeasts and bacteria in their intestines [43,55,57] and feed on phloem that is often infested by ophiostomatoid fungi [16], which is likely to provide ample opportunity for the acquisition of microbial enzymes. If the endo- $\beta-1,4$-xylanase found in larvae of $X$. saxesenii is fungus derived, that would either imply that the fungus exclusively produces endo$\beta-1,4$-xylanase in the structures eaten by the larvae and not by the adults (e.g. it is known that enzyme activity of Ophiostoma species vary between mycelium and asexual fruiting structures [35]) or that the larvae but not the adults avoid internal proteolysis of this enzyme. Irrespective of enzymatic origin, the breakdown of crosslinking glycans within the larval intestinal tract may (i) have a positive influence on larval nutrition and (ii) could be enhanced by active mixing of small woody particles with fungus derived plant cell-wall degrading enzymes.

\section{Conclusions}

Despite differences in the type of substrate used to cultivate symbiotic fungi, a striking, but perhaps not surprising commonality between the major insect fungusgrowing systems is the direct or indirect use of a similar set of fungal carbohydrate active enzymes to utilize recalcitrant plant material as a stable food source (Table 1). Plant cell-wall degrading xylanases, pectinases and to a lesser degree cellulases dominate the enzymatic profiles in all cases, although inherent variation between fungusgrowing systems are certainly present at the level of specific enzymes. Endogenously produced cellulase enzymes are not common among arthropods [63] (for a contrasting view see [58]), which indicate that the provision of essential carbohydrate active enzymes by microbes facilitates fungus farming.

Feeding activity of $X$. saxesenii larvae not only benefits other group members by creating more space for the ambrosia fungus to form ambrosial layers on the gallery walls, but here we show that it also enhances wood degradation and nutrient cycling. Predigested larval feces, which contains small woody particles and probably also enzymes, is smeared on gallery walls after defecation $[21,33]$. The wood particles in this fecal inoculum may be further degraded and nitrogenous excretions recycled by the ambrosia fungi [64]. This may in turn explain the positive effect of larval numbers on group productivity in $X$. saxesenii [21], and demonstrates a synergism between age groups that prevents competition for fungal food, because adults and larvae feed differently and apparently use a complementary set of enzymes. The differences in enzyme profiles of $X$. saxesenii larvae and adults are interesting for understanding the social system of this species. $X$. saxesenii is the only primitively eusocial ambrosia beetle described (characterized by overlapping offspring generations, cooperative brood care and reproductive division of labor) and similarly to the obligatorily eusocial ants, bees and termites exhibit division of labor not only between the sexes, but most importantly also between larval and adult offspring [21]. Differential enzyme activity therefore adds an additional 
Table 1 Overview of highly derived, obligate nutritional symbioses between insects and fungi

\begin{tabular}{|c|c|c|c|c|c|c|c|}
\hline & \multicolumn{3}{|l|}{ Coleoptera } & \multirow{2}{*}{ Diptera } & \multicolumn{2}{|l|}{ Hymenoptera } & \multirow{2}{*}{$\begin{array}{l}\text { Isoptera } \\
\text { Fungus-growing termites }\end{array}$} \\
\hline & Ambrosia beetles & Bark beetles $^{1}$ & Ship-timber beetles & & Wood wasps & Fungus-growing ants & \\
\hline Insect family & Curculionidae & Curculionidae & Lymexylidae & Cecidomyiidae & $\begin{array}{l}\text { Xiphydriidae, Orussidae, } \\
\text { Anaxyelidae, Siricidae }\end{array}$ & Formicidae & Termitidae \\
\hline Mutualistic fungi & $\begin{array}{l}\text { Ascomycota (Ambrosiella, } \\
\text { Raffaelea, Fusarium) }\end{array}$ & $\begin{array}{l}\text { Ascomycota (Ophiostoma, } \\
\text { Ceratocystiopsis, Grosmannia) } \\
\text { Basidiomycota (Entomocorticium) }\end{array}$ & $\begin{array}{l}\text { Ascomycota } \\
\text { (Endomyces) }\end{array}$ & $\begin{array}{l}\text { Ascomycota } \\
\text { (Lasioptera, } \\
\text { Ramichloridium) }\end{array}$ & $\begin{array}{l}\text { Basidiomycota (Cerrena, } \\
\text { Stereum, Amylostereum); } \\
\text { Ascomycota (Daldinia } \\
\text { decipiens, Entonaema } \\
\text { cinnabarina) }\end{array}$ & $\begin{array}{l}\text { Basidiomycota } \\
\text { (Leucocoprinus, } \\
\text { Leucoagaricus and } \\
\text { the family Pterulaceae) }\end{array}$ & $\begin{array}{l}\text { Basidiomycota } \\
\text { (Termitomyces) }\end{array}$ \\
\hline Age of symbiosis(Mya) & $21-60$ & $?$ & $?$ & $?$ & $?$ & $45-65$ & $24-34$ \\
\hline \multicolumn{8}{|l|}{ Agriculture } \\
\hline Mode of nesting & Xylem tunnels \& chambers & Phloem tunnels \& chambers & Xylem tunnels & Plant galls & Xylem tunnels & $\begin{array}{l}\text { Subterranean nests } \\
\text { (occ. mounds) }\end{array}$ & $\begin{array}{l}\text { Subterranean nests } \\
\text { and mounds }\end{array}$ \\
\hline Substrate for fungi & Surrounding wood & $\begin{array}{l}\text { Surrounding phloem } \\
\text { (and wood) }\end{array}$ & Surrounding wood & $\begin{array}{l}\text { Surrounding } \\
\text { plant tissue }\end{array}$ & Surrounding wood & $\begin{array}{l}\text { Collected plant material } \\
\text { (twigs, caterpillar feces, } \\
\text { leaf litter, flowers, fruits, } \\
\text { fresh leaves) }\end{array}$ & $\begin{array}{l}\text { Collected plant material } \\
\text { (dry leaf litter, } \\
\text { twigs, wood) }\end{array}$ \\
\hline Mode of agriculture ${ }^{2}$ & Advanced & $\begin{array}{l}\text { Primitive (possibly advanced } \\
\text { in Dendroctonus) }\end{array}$ & Primitive & $?$ & Primitive & Advanced & Advanced \\
\hline \multicolumn{8}{|l|}{ Enzymatic profile } \\
\hline $\begin{array}{l}\text { Fungus garden (incl. } \\
\text { microbial community) }\end{array}$ & $\begin{array}{l}\text { xylem degrading } \\
\text { saprotrophism and } \\
\text { bionecrotrophism }\end{array}$ & bionecrotrophism of phloem & $?$ & $?$ & $\begin{array}{l}\text { xylem degrading } \\
\text { saprotrophism }\end{array}$ & $\begin{array}{l}\text { Saprotrophism (saprobic } \\
\text { and biotrophic in } \\
\text { leaf-cutting ants) }\end{array}$ & $\begin{array}{l}\text { Saprotrophism } \\
\text { (plant cell-wall } \\
\text { degrading) }\end{array}$ \\
\hline $\begin{array}{l}\text { Fungus acquired } \\
\text { enzymes }^{3}\end{array}$ & Possible ${ }^{5}$ & $?$ & $?$ & $?$ & Present & Present & Present \\
\hline \multicolumn{8}{|l|}{ Mode of feeding ${ }^{4}$} \\
\hline Adults & Mycetophagy & Phloeomycetophagy & No food & Plant sap & No food & $\begin{array}{l}\text { Mycetophagy, } \\
\text { (plant material) }\end{array}$ & $\begin{array}{l}\text { Mycetophagy, } \\
\text { (plant material) }\end{array}$ \\
\hline Larvae & $\begin{array}{l}\text { Mycetophagy } \\
\left(\text { Xylomycetophagy }{ }^{6}\right)\end{array}$ & Phloeomycetophagy & Xylomycetophagy & Mycetophagy & Xylomycetophagy & Mycetophagy & Mycetophagy \\
\hline
\end{tabular}

${ }^{1}$ Here we only refer to bark beetles in nutritional symbioses with fungi and omit species only feeding on phloem

2 Primitive fungiculture is defined by only dispersal and seeding of fungi; advanced fungiculture additionally involves the active care of fungal crops (cf. [9]).

${ }^{3}$ Evidence for fungus acquired enzymes that are active in the insect gut or fecal exudates [13,62].

${ }^{4}$ Distinctions originating from the scolytine beetle literature e.g. [20]: Mycetophagy = eating fungal mycelium, fruiting bodies or specific fungal structures, Phloeomycethophagy = eating phloem and fungal biomass, Xylomycetophagy $=$ eating $x y l e m$ and fungal biomass.

${ }^{5}$ Reference: this study.

${ }^{6}$ Only in larvae of the genus Xyleborinus and probably Xylosandrus [21,32]. 
layer of complexity to the behavioural division of labour between adults and larvae. Production of extra enzymes and nutrients by larvae (and their trophallaxis to adults) has been reported from other social insects, such as ants and wasps [65-67], and larvae of the leaf-cutting ant Acromyrmex subterraneous have even been denoted the "digestive caste" of the colony based on the extensive enzymatic machinery detected in their gut lumen [68]. Holometabolous insects dramatically restructure morphology and physiology during metamorphosis and phenotypes of larval and adult stages thus represent distinct developmental and evolvable modules compared with the highly correlated life stages of insects with "incomplete" metamorphosis (Hemimetabola) [69]. Because of this predisposition we propose that larvae in holometabolous insect societies may play a much more important role in resource utilization than is currently recognized.

\section{Materials and methods Laboratory breeding}

$X$. saxesenii adult females were collected in the Spilwald forest ( $560 \mathrm{~m}$ asl; $46^{\circ} 95^{\prime}, 7^{\circ} 31^{\prime}$ ) close to Bern, Switzerland in January 2010, by dissection of galleries from stumps of beech trees (Fagus sylvatica) that had been cut about a year earlier. From these galleries adult $X$. saxesenii females were brought to the laboratory and placed individually in $\sim 15 \mathrm{~mL}$ plastic tubes filled with a sterile nutrient-enriched beech saw-dust media solidified with agar as previously described [50]. X. saxesenii galleries typically consist of a straight entrance tunnel dug perpendicular into the media for about $2-5 \mathrm{~cm}$ where it reaches a flat brood chamber of $2-3 \mathrm{~cm}^{2}$ and a height of $1 \mathrm{~mm}$ (Figure 1A, [Additional file 1: Figure S3]). Three distinct gallery compartments - entrance tunnel, brood chamber and gallery dump material - may be discerned both in laboratory galleries in artificial media and field galleries constructed in wood. X. saxesenii is obligately sib-mating (inbreeding) within the natal nest and dispersing females vertical transmit the associated mutualistic symbionts in mycetangia [21]. Dispersing adults can be collected from the surface of the media and thus enables breeding of consecutive generations in the laboratory.

Galleries used in this study were from the $5^{\text {th }}$ laboratory generation. Sampling from laboratory ambrosia beetle galleries is preferable to sampling from field galleries, because this allows (i) to control the age of the galleries (and thereby changes in the fungal composition) and (ii) to monitor fungal diversity and the number of beetles and their behavior. Laboratory breeding of ambrosia beetles also has disadvantages, because symbiont composition may differ between laboratory and field galleries. Although it is unlikely that new microbes have invaded the system, because of the highly specialized vertical transmission of the primary mutualists in beetle mycetangia and relatively few other secondary microbes on the integument [14], it is possible that relative composition of symbionts has changed in response to the different conditions within the laboratory. Changes are probably negligible, however, because ambrosia beetles have up to now (March 2012) been reared for ten successive generations within the laboratory and major changes in gallery productivity across generations are absent, which indicates that the abundance of the primary symbionts in the microbiome is unaffected by long-term laboratory rearing [unpublished data (Biedermann PHW)].

\section{Sampling and protein extraction}

In this study we collected samples from laboratory maintained galleries at three particular time points during gallery development: (A) At day 45 after gallery foundation (= age 45) when few adults, but many $1^{\text {st }}$ and $2^{\text {nd }} / 3^{\text {rd }}$ instar larvae are present in the gallery and the microbiome is dominated by the Raffaelea sulfurea symbiont [24]. (B) At day 62 after gallery foundation (= age62) when few immature brood, but many more adults that are just starting to disperse are present in the gallery. The microbiome has changed and is no longer completely dominated by $R$. sulfurea, but contains also a mixture of several saprobes (e.g. Paecilomyces and Penicillium species; [24]. (C) At day 87 after gallery foundation (= age87) when production of new brood has ceased and almost all adult offspring has left the gallery. The microbiome is dominated by a few saprobic species, which are probably of little nutritional value to the beetles [24].

When sampling, we removed the solid agar-sawdust based medium containing the beetle galleries from the plastic tube in a single large piece and subsequently dissected it using a scalpel and forceps. Thirty mg (wet weight) of gallery material from the three distinct gallery compartments: (I) entrance tunnel, (II) brood chamber, and (III) expelled material from the gallery dump were collected and weighed on an electronic scale (0.0001 g precision). Total proteins were extracted from each sample, put in an Eppendorf tube filled with $260 \mu \mathrm{dddH}_{2} 0$ and $0.1 \%$ Tween 20 , and ground with a small plastic pestle. Tween 20 was added to the extraction water to keep enzymes in suspension [70]. Samples were vortexed, centrifuged at $15.000 \mathrm{~g}$ for $15 \mathrm{~min}$ at $4{ }^{\circ} \mathrm{C}$ and enzyme activity of the supernatant fraction was immediately measured to minimize internal proteolysis. In total 11, 15 and 8 galleries from age45, age62 and age87, respectively, were used giving a total sample size of 34 galleries times three compartments (11 gallery dump samples had to be discarded as there was not enough material). In addition, we counted all individuals $\left(1^{\text {st }}\right.$ instar, $2^{\text {nd }} / 3^{\text {rd }}$ instar larvae, and adults) present within a gallery at that time. 
In addition to sampling gallery material we also measured individuals for enzyme activity. First instar larvae, $2^{\text {nd }} / 3^{\text {rd }}$ instar larvae and adult beetles were collected at age 45, when all developmental stages of $X$. saxesenii were present within galleries. All individuals were surface sterilized once in bleach and once in 96\% alcohol. Three adults, four $2^{\text {nd }} / 3^{\text {rd }}$ instar larvae and twelve $1^{\text {st }}$ instar larvae were combined per sample to standardize the amount of biological material to approximately $30 \mathrm{mg}$ biomass. Thereafter, samples were grinded in $60 \mu \mathrm{l}$ $\mathrm{ddH}_{2} \mathrm{O}$ containing $0.1 \%$ Tween 20 , vortexed, centrifuged (see above) and immediately used for enzyme activity measurements.

\section{Enzyme activity measurements}

Enzyme activity was assayed with Azurine-Crosslinked (AZCL) polysaccharides that are purified polysaccharides cross-linked with a blue dye to form a water insoluble substrate, which is commercially available from Megazyme $^{\odot}$ (Bray, Ireland) in the form of a powder (Table 2). Assay plates were prepared as previously described [71,72] with a medium consisting of $1 \%$ agarose, $23 \mathrm{mM}$ phosphoric acid, $23 \mathrm{mM}$ acetic acid and $23 \mathrm{mM}$ boric acid, mixed and adjusted to $\mathrm{pH}=6$. The medium was heated using a microwave to melt the agarose. When the medium had cooled to $65{ }^{\circ} \mathrm{C}, 0.1 \%$ weight/volume AZCL substrate wetted in $96 \%$ ethanol was added. The medium was then poured into Petri dishes and allowed to

\section{Table 2 Insoluble chromogenic substrates used to test for enzyme activity and the specific type of enzymes} measured

\begin{tabular}{|c|c|}
\hline Substrate & Enzyme \\
\hline \multicolumn{2}{|l|}{ Cellulose } \\
\hline AZCL-HE-Cellulose & cellulase (endo- $\beta-1,4-g l u c a n a s e)$ \\
\hline AZCL-Barley $\beta$-Glucan & cellulase (endo- $\beta-1,3(4)$-glucanase) \\
\hline AZCL-Xyloglucan & endo- $\beta-1,4-x y l o g l u c a n a s e$ \\
\hline \multicolumn{2}{|l|}{ Hemicellulose } \\
\hline AZCL-Xylan & endo- $\beta-1,4-x y l a n a s e$ \\
\hline AZCL-Arabinoxylan & endo- $\beta-1,4-x y l a n a s e$ \\
\hline AZCL-Dextran & endo-a-1,6-dextranase \\
\hline \multicolumn{2}{|l|}{ Pectin } \\
\hline AZCL-Debranched Arabinan & endo-a-1,5-arabinase \\
\hline AZCL-Rhamnogalacturonan & rhamnogalacturonanase \\
\hline AZCL-Galactomannan & endo- $\beta-1,4-m a n n a n a s e$ \\
\hline AZCL-Galactan & endo- $\beta-1,4-g a l a c t a n a s e$ \\
\hline \multicolumn{2}{|l|}{ Protein } \\
\hline AZCL-Casein & endo-protease \\
\hline AZCL-Collagen & endo-protease \\
\hline \multicolumn{2}{|l|}{ Starch } \\
\hline AZCL-Amylose & a-amylase \\
\hline
\end{tabular}

solidify. Thereafter, we made five wells $\left(\sim 4 \mathrm{~mm}^{2}\right)$ per plate using a cut-off pipette tip, applied $15 \mu$ l supernatant of each protein enzyme extract per well, and incubated the plates at room temperature (ca. $21{ }^{\circ} \mathrm{C}$ ) in the dark. After $24 \mathrm{~h}$ all plates were photographed for quantifying the area of the blue halo surrounding each well with image analysis software (ImageJ ver. $1.37 \mathrm{v}, \mathrm{W}$. Rasband, http://rsb.info.nih.gov/ij/). A positive enzyme reaction lead to the release of dyed water soluble fragments into the agarose medium and the area of blue coloration is thus a quantitative measure for enzyme activity that can be compared between samples [71-73], although it does not provide absolute values of enzyme activity [74]. 13 AZCL substrates were tested for enzyme activity (Table 2), except for the larval and adult beetle samples that were only tested for endo- $\beta-1,4$-glucanase,

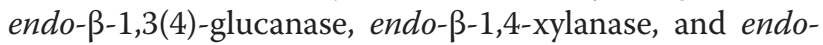
protease activity because of insufficient extracts to test for all 13 substrates. A pilot study showed no activity of either gallery, beetle or larval extracts against the substrates AZCL-pullulan, AZCL-chitosan, AZCL-curdlan, and AZCL-pachyman and therefore results for these substrates were not shown here.

\section{Data analysis}

Enzyme activity of the gallery data were ' $\log +1$ ' transformed to normalize the data. Enzyme activity were analyzed for each substrate in separate mixed linear models with (A) the three factorial variables (i) gallery compartment (three levels: 'entrance,' 'brood chamber' and 'gallery dump'), (ii) the interaction between gallery compartment and age of the gallery (three levels: age45, age62 and age87), (iii) the interaction between gallery compartment and beetle composition (three levels: 'adult beetles and immatures present,' 'only immatures present' and 'no beetles or larvae present') and (B) the continuous variables (i) total number of adults and (ii) total number of larvae. All variables were included as fixed effects. Each gallery was assigned a code that was included as a random factor in all models because entrance, brood chamber and gallery dump samples from the same gallery are not independent measurements. Model estimation was performed with Maximum Likelihood using the lme function implemented in $\mathrm{R}$ [75] and each variable was evaluated by ANOVA analysis of log-likelihood scores using a step-wise model reduction scheme. Specific means were compared with Tukey's multiple comparisons of the final model. The correlation between a particular enzyme activity and the three sample gallery compartments were analyzed using partial least square regression of a matrix consisting of three $\mathrm{x}$-variables (sample location: entrance tunnel, brood chamber and gallery dump) and $13 \mathrm{y}$-variables (enzyme activity for 
each substrate screened) using the $\mathrm{R}$ package pls [76] [see Additional file 1].

\section{Additional file}

Additional file 1 Supplementary Online Material. Additional figures supporting the data analysis.

\section{Competing interests}

The authors declare that they have no competing interests.

\section{Acknowledgements}

The authors thank Marko Rohlfs, Anders Tunlid, Morten Schiøtt and three anonymous reviewers for helpful comments on a previous version of this manuscript and Jacobus J. Boomsma for providing the AZCL reagents. HHdFL gratefully acknowledges the M. P. Christiansen and wife foundation administered by the Danish Mycological Society for a research travel grant. HHdFL is supported by a fellowship from the Danish Research Council | Natural Sciences and PHWB partially by a DOC fellowship of the Austrian Academy of Sciences and by a fellowship of the Roche Research Foundation.

\section{Author details}

Microbial Ecology Group, Department of Biology, Lund University, Ecology Building, Solvegatan 37, SE-22362, Lund, Sweden. ${ }^{2}$ Department of Behavioural Ecology, Institute of Ecology \& Evolution, University of Bern, Baltzerstrasse 6, CH-3012, Bern, Switzerland.

\section{Authors' contributions}

HHDFL and PHWB designed the study. PHWB collected and maintained laboratory beetle galleries. HHDFL and PHWB conducted enzyme measurements and HHDFL analyzed the data. HHDFL and PHWB wrote the manuscript in collaboration. All authors read and approved the final manuscript.

\section{Authors' information}

HHDFL is postdoctoral fellow at the Microbial Ecology Group at Lund University, Sweden, and studies the ecology and evolution of mutualistic systems. PHWB is Ph.D. student at the Department of Behavioural Ecology at University of Bern, Switzerland. PHWB studies the evolutionary mechanisms of social and mutualistic interactions.

Received: 15 March 2012 Accepted: 6 June 2012

Published: 6 June 2012

\section{References}

1. Mora C, Tittensor DP, Adl S, Simpson AGB, Worm B: How many species are there on earth and in the ocean. PLOS Biol 2011, 9:e1001127.

2. Bourtzis K, Miller TA: Insect symbiosis. Boca Raton: CRC Press; 2003.

3. Hillis WE: Heartwood and tree exudates. New York: Springer; 1987.

4. Warnecke $F$, Luginbuhl $P$, Ivanova N, Ghassemian M, Richardson $T H$, Stege JT, Cayouette M, McHardy AC, Djordjevic G, Aboushadi N, Sorek R, Tringe SG, Podar M, Martin HG, Kunin V, Dalevi D, Madejska J, Kirton E, Platt D, Szeto E, Salamov A, Barry K, Mikhailova N, Kyrpides NC, Matson EG, Ottesen EA, Zhang XN, Hernandez M, Murillo C, Acosta LG, et al: Metagenomic and functional analysis of hindgut microbiota of a wood-feeding higher termite. Nature 2007, 450:560-U517.

5. Martin MM: Invertebrate-microbial interactions. Ithaca: Cornell University Press; 1987.

6. Grunwald S, Pilhofer M, Holl W: Microbial associations in gut systems of wood- and bark-inhabiting longhorned beetles [Coleoptera: Cerambycidae]. Syst Appl Microbiol 2010, 33:25-34

7. Anagnostou C, Dorsch M, Rohlfs M: Influence of dietary yeasts on Drosophila melanogaster life-history traits. Entomol Exp Appl 2010, 136:1-11.

8. Hammond PM, Lawrence JF: Mycophagy in insects: A summary. In Insectfungus interactions. Symposia of the Royal Entomological Society of London, 14, London. Academic Press 1989;275-283.
9. Mueller UG, Gerardo NM, Aanen DK, Six DL, Schultz TR: The evolution of agriculture in insects. Annu Rev Ecol Syst 2005, 36:563-595.

10. Ayres MP, Wilkens RT, Ruel JJ, Lombardero MJ, Vallery E: Nitrogen budgets of phloem-feeding bark beetles with and without symbiotic fungi. Ecology 2000, 81:2198-2210.

11. Hunt DWA, Borden JH: Conversion of Verbenols to verbenone by yeasts isolated from Dendroctonus ponderosae (Coleoptera, Scolytidae). J Chem Ecol 1990, 16:1385-1397.

12. Dowd PF: Insect fungal symbionts - A promising source of detoxifying enzymes. J Ind Microbiol 1992, 9:149-161.

13. Kukor JJ, Martin MM: Acquisition of digestive enzymes by Siricid woodwasps from their fungal symbiont. Science 1983, 220:1161-1163.

14. Francke-Grosmann H: Hautdrüsen als Träger der Pilzsymbiose bei Ambrosiakäfern. Z Morphol Tiere 1956, 45:275-308

15. Francke-Grosmann $\mathrm{H}$ : Ectosymbiosis in wood-inhabiting beetles. In symbiosis. Edited by Henry SM. New York: Academic; 1967:141-205.

16. Six DL: Bark beetle-fungus symbioses. In Insect Symbiosis. Edited by Bourtzis K, Miller TA. Boca Raton: CRC Press; 2003:97-114.

17. Grebennikov W, Leschen RAB: External exoskeletal cavities in Coleoptera and their possible mycangial functions. Entomol Sci 2010, 13:81-98.

18. Farrell BD, Sequeira AS, O'Meara BC, Normark BB, Chung JH, Jordal BH: The evolution of agriculture in beetles (Curculionidae: Scolytinae and Platypodinae). Evolution 2001, 55:2011-2027.

19. Hulcr J, Kolarik M, Kirkendall LR: A new record of fungus-beetle symbiosis in Scolytodes bark beetles (Scolytinae, Curculionidae, Coleoptera). Symbiosis 2007, 43:151-159.

20. Beaver RA: Insect-fungus relationships in the bark and ambrosia beetles In Insect-fungus interactions. Edited by Wilding N, Collins NM, Hammond PM, Webber JF. London: Academic; 1989:121-143.

21. Biedermann PHW, Taborsky M: Larval helpers and age polyethism in ambrosia beetles. Proc Natl Acad Sci USA 2011, 108:17064-17069.

22. Harrington TC: Ecology and evolution of mycophagous bark beetles and their fungal partners. In Insect-fungal associations. New York: Oxford University Press; 2005:257-295.

23. Kajimura $\mathrm{H}, \mathrm{Hijii} \mathrm{N}$ : Dymamics of the fungal symbionts in the gallery system and the mycangia of the ambrosia beetle, Xylosandrus mutilatus (Blandford) (Coleoptera, Scolytidae). Ecol Res 1992, 7:107-117

24. Biedermann PHW: Evolution of cooperation in ambrosia beetles. PhD thesis. University of Bern, Institute of Ecology and Evolution; 2012.

25. Kurtzman CP, Robnett CJ: Three new insect-associated species of the yeast genus Candida. Can J Microbiol 1998, 44:965-973.

26. Haanstad JO, Norris DM: Microbial symbiotes of the ambrosia beetle Xyletorinus politus. Microb Ecol 1985, 11:267-276.

27. Grubbs KJ, Biedermann PHW, Suen G, Adams SM, Moeller JA, Klassen Jl, Goodwin LA, Woyke T, Munk AC, Bruce D, et al: The complete genome sequence of Streptomyces cf. griseus (XyelbKG-1), an Ambrosia beetleassociated Actinomycete. J Bacteriol 2011, 193:2890-2891.

28. Roeper RA, French JRJ: Ambrosia fungi of the Western United States and Canada - beetle assocaitions (Coleoptera: Scolytidae), tree hosts, and distribution. Northwest Science 1981, 55:305-309.

29. Kirisits T: Fungal associates of European bark beetles with special emphasis on the ophiostomatoid fungi. In Bark and Wood Boring Insects in Living Trees in Europe, a Synthesis. Edited by Lieutier F, Keith RD, Battisti A, Gregoire JC, Evans HF. Dordrecht: Springer; 2004:181-237.

30. Alamouti SM, Tsui CKM, Breuil C: Multigene phylogeny of filamentous ambrosia fungi associated with ambrosia and bark beetles. Mycol Res 2009, 113:822-835

31. Endoh R, Suzuki M, Okada G, Takeuchi Y, Futai K: Fungus symbionts colonizing the galleries of the Ambrosia beetle Platypus quercivorus. Microb Ecol 2011, 62:106-120

32. Roeper RA: Patterns of mycetophagy in Michigan ambrosia beetles. Michigan Academian 1995, 27:153-161.

33. Hubbard HG: Some miscellaneous results of the work of the division of entomology. In US department of agriculture bureau of entomology bulletin No 7. Edited by Howard LO. Washington, DC: US department of agriculture: 1897.

34. Przybyl K, Dahm H, Ciesielska A, Molinski K: Cellulolytic activity and virulence of Ophiostoma ulmi and O. novo-ulmi isolates. Forest Pathol 2006, 36:58-67. 
35. Binz T, Canevascini G: Xylanases from the Dutch elm disease pathogens Ophiostoma ulmi and Ophiostoma novo-ulmi. Physiol Mol Plant P 1996, 49:159-175.

36. Svaldi R, Elgersma DM: Further studies on the activity of cell wall degrading enzymes of aggressive and non-aggressive isolates of Ophiostoma ulmi. Eur J Forest Pathol 1982, 12:29-36.

37. Nilsson T: Soft-rot fungi - decay patterns and enzyme production. In Organismen und Holz. Edited by Becker G, Liese W. Berlin: Duncker und Humblot; 1976:103-112.

38. Tamerler C, Keshavarz T: Lipolytic enzyme production in batch and fedbatch cultures of Ophiostoma piceae and Fusarium oxysporum. J Chem Tech Biotech 2000, 75:785-790.

39. Parkin EA: The digestive enzymes of some woodboring beetle larvae. J Exp Biol 1940, 17:364-377

40. Balogun RA: Digestive enzymes of alimentary canal of larch bark beetle Ips cembrae Heer. Comp Biochem Physiol 1969, 29:1267-1270.

41. Valiev A, Ogel ZB, Klepzig KD: Analysis of cellulase and polyphenol oxidase production by southern pine beetle associated fungi. Symbiosis 2009, 49:37-42.

42. Geib SM, Filley TR, Hatcher PG, Hoover K, Carlson JE, Jimenez-Gasco MD, Nakagawa-Izumi A, Sleighter RL, Tien M: Lignin degradation in woodfeeding insects. Proc Natl Acad Sci USA 2008, 105:12932-12937.

43. Rivera FN, Gonzalez E, Gomez Z, Lopez N, Hernandez-Rodriguez C, Berkov A, Zuniga G: Gut-associated yeast in bark beetles of the genus Dendroctonus erichson (Coleoptera: Curculionidae: Scolytinae). Biol J Linn Soc 2009, 98:325-342.

44. Schmidt O, Dietrichs HH: Zur Aktivität von Bakterien gegenüber Holzkomponenten. In Organismen und Holz. Edited by Becker G, Liese W. Berlin: Duncker und Humblot; 1976:91-102.

45. Delalibera I, Handelsman J, Raffa KF: Contrasts in cellulolytic activities of gut microorganisms between the wood borer, Saperda vestita (Coleoptera: Cerambycidae), and the bark beetles, Ips pini and Dendroctonus frontalis (Coleoptera: Curculionidae). Environ Entomol 2005, 34:541-547.

46. Rosch R, Liese W, Berndt H: Studies on enzymes of blue-stain fungi .I. Cellulase-, Polygalacturonase-, Pectinesterase- and Laccase-Activity. Arch Mikrobiol 1969, 67:28-50

47. Binz T, Gremaud C, Canevascini G: Production and purification of an extracellular beta-galactosidase from the Dutch elm disease fungus Ophiostoma novo-ulmi. Can J Microbiol 1997, 43:1011-1016.

48. Beckman $\mathrm{CH}$ : Production of Pectinase, Cellulases, and growthpromoting substance by Ceratostomella Ulmi. Phytopathology 1956, 46:605-609.

49. Vega FE, Dowd PF: The role of yeasts as insect endosymbionts. In InsectFungal Assocations: Ecology and Evolution. Edited by Vega FE, Blackwell M. New York: Oxford University Press; 2005:211-243.

50. Biedermann PHW, Klepzig KD, Taborsky M: Fungus cultivation by ambrosia beetles: behavior and laboratory breeding success in three xyleborine species. Environ Entomol 2009, 38:1096-1105.

51. Cooke RC, Rayner ADM: Ecology of saprotrophic fungi. Harlow: Longmann Group limited; 1984

52. Dighton J: Nutrient cycling by saprotrophic fungi in terrestrial habitats. In The Mycota IV: Environmental and microbial relationships. Edited by Esser K, Lemke PA. Berlin: Springer Verlag; 1997:287-300.

53. Dix NJ, Webster J: Fungal Ecology. London: Chapman \& Hall; 1995.

54. Scott JC, Budsberg KJ, Suen G, Wixon DL, Balser TC, Currie CR: Microbial community structure of leaf-cutter ant fungus gardens and refuse dumps. PLOS One 2010, 5:3. doi:10.1371/journal.pone.0009922.

55. Delalibera I, Vasanthakumar A, Burwitz BJ, Schloss PD, Klepzig KD, Handelsman J, Raffa KF: Composition of the bacterial community in the gut of the pine engraver, Ips pini (Say) (Coleoptera) colonizing red pine. Symbiosis 2007, 43:97-104.

56. Bridges JR: Nitrogen-fixing bacteria associated with bark beetles. Microb Ecol 1981, 7:131-137.

57. Vasanthakumar A, Delalibera I, Handelsman J, Klepzig KD, Schloss PD, Raffa KF: Characterization of gut-associated bacteria in larvae and adults of the southern pine beetle, Dendroctonus frontalis Zimmermann. Environ Entomol 2006, 35:1710-1717.

58. Pauchett $Y$, Wilkinson P, Chauhan R, Ffrench-Constant RH: Diversity of beetle genes encoding novel plant cell wall degrading enzymes. PLOS One 2010, 5:5. doi:10.1371/journal.pone.0015635.
59. Kikuchi T, Shibuya $H$, Jones JJ: Molecular and biochemical characterization of an endo- $\beta-1,3$-glucanase from the pinewood nematode Bursaphelenchus xylophilus acquired by horizontal gene transfer from bacteria. Biochem J 2005, 389:117-125.

60. Song JM, Nam K, Sun YU, Kang MH, Kim CG, Kwon ST, Lee J, Lee YH: Molecular and biochemical characterizations of a novel arthropod endo-beta-1,3glucanase from the Antarctic springtail, Cryptopygus antarcticus, horizontally acquired from bacteria. Comp Biochem Phys B 2010, 155:403-412.

61. Girard C, Jouanin L: Molecular cloning of $c D N A s$ encoding a range of digestive enzymes from a phytophagous beetle, Phaedon cochleariae. Insect Biochem Molec 1999, 29:1129-1142.

62. Martin MM, Martin JS: Cellulose digestion in the midgut of the fungusgrowing termite Macrotermes natalensis: The role of acquired digestive enzymes. Science 1977, 199:1453-1455.

63. Watanabe H, Tokuda G: Animal cellulases. Cell Mol Life Sci 2001, 58:1167-1178,

64. Norris DM: Chemical interdependence among Xyleborus spp. ambrosia beetles and their symbiotic microbes. Mater Organismen 1975, 3:479-788.

65. Ishay J, Ikan R: Food exchange between adults and larvae in Vespa orientalis F. Anim Behav 1968, 16:298-303.

66. Hunt JH, Baker I, Baker HG: Similarity of amino-acids in nectar and larval saliva - the nutritional basis for trophallaxis in social wasps. Evolution 1982, 36:1318-1322

67. Hölldobler B: Wilson EO: The Ants. Cambridge: Harvard University Press; 1990.

68. Erthal MJ, Silva CP, Samuels RI: Digestive enzymes in larvae of the leaf cutting ant, Acromyrmex subterraneus (Hymenoptera: Formicidae: Attini). J Insect Physiol 2007, 53:1101-1111.

69. Yang AS: Modularity, evolvability, and adaptive radiations: a comparison of the hemi- and holometabolous insects. Evol Dev, 3:59-72.

70. Pedersen $M$, Hollensted $M$, Lange $L$, Andersen B: Screening for cellulose and hemicellulose degrading enzymes from the fungal genus Ulocladium. Int Biodeter Biodegr 2009, 63:484-489.

71. De Fine Licht HH, Schiøtt M, Mueller UG, Boomsma JJ: Evolutionary transitions in enzyme activity of ant fungus gardens. Evolution 2010 64:2055-2069

72. Schiøtt M, De Fine Licht HH, Lange L, Boomsma JJ: Towards a molecular understanding of symbiont function: Identification of a fungal gene for the degradation of xylan in the fungus gardens of leaf-cutting ants. BMC Microbiol 2008, 8

73. Kooij PW, Schiott M, Boomsma JJ, Licht HHD: Rapid shifts in Atta cephalotes fungus-garden enzyme activity after a change in fungal substrate (Attini, Formicidae). Insec Soc 2011, 58:145-151.

74. Ten LN, Im W-T, Kim M-K, Kang MS, Lee S-T: Development of a plate technique for screening of polysaccharide-degrading microorganisms by using a mixture of insoluble chromogenic substrates. J Microb Methods 2004, 56:375-382.

75. R development core team: $R$ : A language and environment for statistical computing. Vienna, Austria:; 2011.

76. Mevik BH, Wehrens $\mathrm{R}$ : The pls package: principal component and partial least squares regression in R. J stat softw 2007, 18:1-24.

doi:10.1186/1742-9994-9-13

Cite this article as: De Fine Licht and Biedermann: Patterns of functional enzyme activity in fungus farming ambrosia beetles. Frontiers in Zoology 2012 9:13.

\section{Submit your next manuscript to BioMed Central and take full advantage of:}

- Convenient online submission

- Thorough peer review

- No space constraints or color figure charges

- Immediate publication on acceptance

- Inclusion in PubMed, CAS, Scopus and Google Scholar

- Research which is freely available for redistribution 